Ann. Biol. anim. Bioch. Biophys., 1979, 19 (2A), 393-404.

\title{
Diurnal changes in blood ketone bodies, glucose and lipids according to energy intake in adult sheep
}

\author{
by Françoise DOIZE, J. CI. BOUCHAT, R. PAQUAY \\ Laboratoire de Physiologie animale, Facultés Universitaires Notre-Dame-de-la-Paix, \\ B-5000 Namur, Belgium.
}

\begin{abstract}
Summary. In order to establish the daily evolution of different blood components according to energy intake in sheep, blood samples were taken every hour during three periods of 24 or $48 \mathrm{hrs}$. The animals were underfed, fed at maintenance level or fed ad libitum. A rapid increase of blood aceloacetate and $\beta$-hydroxybutyrate generally occurred 1 to 2 hrs after feeding. Daily fluctuations were larger in animals fed in a limited way than in those fed ad libitum. The mean daily blood concentration of ketone bodies depended more on individual differences than on the intake level. Food ingestion also induced an increase of glycemia, but it was not as evident as that of the ketone bodies and occurred later ( 3 or 4 hrs after feeding) ; glycemia also appeared to increase during the night. The level of food intake had no effect on mean blood glucose content nor on its evolution during the day. We could not conclude that there was an evolution of blood lipids in regard to their distribution, FFA content or FFA distribution during the day. It was also impossible to demonstrate an effect of food level intake on the blood lipids.
\end{abstract}

\section{Introduction.}

The experiments were carried out in our laboratory on the long-term control of voluntary food intake in sheep. We tried to determine the evolution of the concentration of different blood substances in animals placed in metabolic cages and submitted to variable food conditions during long periods of time (several months). In order to determine the possible influence of fattening and food intake level, the direct effect of food ingestion on blood composition had to be eliminated as much as possible. To do this, we had to determine at what moment of the day food intake would have the least influence.

During the last decade, a number of authors have studied the blood composition of ruminants and established the daily evolution of numerous substances. They also ascertained the effect of dietary conditions, and more particularly of food and energy intake levels, on these substances. Their findings are sometimes contradictory. The results in this paper were obtained from tests to determine the daily evolution of blood ketone bodies, glucose and lipids in our experimental conditions, i.e. sheep placed in metabolic cages and maintained on diets with varying energy intakes. 


\section{Material and methods.}

A summary of the experimental design is found in table 1.

\section{TABLE 1}

Experimental design of the study

\begin{tabular}{|c|c|c|c|c|c|c|c|c|c|}
\hline \multirow[b]{2}{*}{$\begin{array}{l}\text { No of } \\
\text { fests }\end{array}$} & \multirow[b]{2}{*}{ Dates } & \multirow[b]{2}{*}{ Treatment } & \multirow[b]{2}{*}{$\begin{array}{l}\text { No of } \\
\text { sheep }\end{array}$} & \multirow[b]{2}{*}{ Sex } & \multirow[b]{2}{*}{$\begin{array}{c}\text { Age } \\
\text { (years) }\end{array}$} & \multirow{2}{*}{$\begin{array}{c}\text { Weight } \\
\text { (beginn- } \\
\text { ing of the } \\
\text { test, } \mathrm{kg} \text { ) }\end{array}$} & \multicolumn{3}{|c|}{ Feed $(\mathrm{kg})$} \\
\hline & & & & & & & $\begin{array}{c}\text { Pasture } \\
\text { hay }\end{array}$ & $\begin{array}{l}\text { Alfalfa } \\
\text { pellets }\end{array}$ & $\begin{array}{c}\text { Concentrated } \\
\text { mixture }\end{array}$ \\
\hline 1 & $\begin{array}{l}\text { From } 17 \text { February } 77 \\
\text { to } 3 \text { March } 77\end{array}$ & $\begin{array}{l}\text { Overfed } \\
\text { Underfed }\end{array}$ & $\begin{array}{l}\text { A } \\
\text { B }\end{array}$ & $\begin{array}{l}q \\
q \\
q\end{array}$ & $\begin{array}{l}6 \\
5\end{array}$ & $\begin{array}{l}69 \\
63\end{array}$ & $\begin{array}{l}0.5 \\
0.2\end{array}$ & - & $\begin{array}{l}\text { ad lib. }\left({ }^{a}\right) \\
0.3 \quad(b)\end{array}$ \\
\hline & $\begin{array}{l}\text { From } 5 \text { August } 77 \\
\text { to } 29 \text { August } 77\end{array}$ & $\begin{array}{l}\text { Preexperimental } \\
\text { for tests } 2 \& 3\end{array}$ & & & & & 0.4 & 0.25 & $0.25 \quad\left(^{c}\right)$ \\
\hline 2 & $\begin{array}{l}\text { From } 29 \text { August } 77 \\
\text { to } 11-12 \text { January } 78\end{array}$ & $\begin{array}{l}\text { Overfed } \\
\text { Control }\end{array}$ & $\begin{array}{l}C \\
D\end{array}$ & $\begin{array}{l}\text { o } \\
\text { o }\end{array}$ & $\begin{array}{l}3 \\
3\end{array}$ & $\begin{array}{l}87 \\
57\end{array}$ & $\begin{array}{l}0.3 \\
0.3\end{array}$ & - & $\begin{array}{ll}\text { ad lib. }\left({ }^{d}\right) \\
0.5 & (d)\end{array}$ \\
\hline 3 & $\begin{array}{l}\text { From } 29 \text { August } 77 \\
\text { to } 16 \text { March } 78 \\
\text { From } 23 \text { February } 78 \\
\text { to } 16 \text { March } 78\end{array}$ & $\begin{array}{l}\text { Overfed } \\
\text { Overfed } \\
\text { Control } \\
\text { Control }\end{array}$ & $\begin{array}{l}E \\
F \\
G \\
H\end{array}$ & $\begin{array}{l}0 \\
0 \\
0 \\
+ \\
+ \\
0 \\
0\end{array}$ & $\begin{array}{l}3 \\
3 \\
2 \\
6\end{array}$ & $\begin{array}{r}99 \\
107 \\
49 \\
63\end{array}$ & $\begin{array}{l}0.3 \\
0.3 \\
0.3 \\
0.3\end{array}$ & $\begin{array}{l}- \\
E\end{array}$ & $\begin{array}{l}\text { ad lib. }(d) \\
\text { ad lib. }\left({ }^{d}\right) \\
0.5 \quad(d) \\
\left.0.5 \quad{ }^{d}\right)\end{array}$ \\
\hline
\end{tabular}

(a) 70 p. 100 commercial mixture, 30 p. 100 crushed oats.

(b) 50 p. 100 commercial mixture, 50 p. 100 crushed oats.

(c) 100 p. 100 commercial mixture.

(d) 40 p. 100 dried beet pulp, 30 p. 100 dehydrated alfalfa, 30 p. 100 cereals.

Test 1. - The first test was carried out between March 1 and 3, 1977 using 2 Suffolk ewes of medium fattening state. They were given a ration composed of pasture hay and a concentrate mixture for 15 days. The hay composition was as follows: 94.7 p. 100 dry matter, 5.6 p. 100 mineral matter, 6.4 p. 100 protein and 29.8 p. 100 crude fiber. The concentrate mixture contained 90-91 p. 100 dry matter, 4-5 p. 100 mineral matter, 14 p. 100 protein and 6.7 p. 100 crude fiber. The hay was given at 10 a.m. and the concentrate at $11: 30$ a.m. ; food refusals were weighed daily. Water was always available. The sheep were put into individual metabolic cages and given artificial light simulating external conditions. Blood samples were taken every hour for a 48-hr period starting at $8: 45$ a.m., which is the usual time for blood sampling in our laboratory.

Before the tests were started, the animals were perfectly adapted to the experimenters and to handling ; they often did not get up or stop ruminating during blood sampling. Blood sampling therefore was not considered as stressing the animals. All blood samples were taken by jugular puncture and the blood was collected in hepa- 
rinized tubes. One sample was taken for ketone body assay, and the remainder was centrifuged for analysis of the plasma lipids.

Tests 2 and 3. - These tests were carried out during a long-term experiment. For 1 month, Suffolk sheep were given the same ration. The animals were then divided into 2 groups; the control group received a maintenance ration and the second group was fed ad libitum. From February 23, 1978 a supplementary sheep (sheep H) was added to the control group. The pasture hay distributed during the experiment contained 88.6 p. 100 dry matter, 9.6 p. 100 mineral matter and 8.7 p. 100 protein, while the concentrate given from August 29 had 90.7 p. 100 dry matter, 8.5 p. 100 mineral matter and 13.2 p. 100 protein. Sheep were weighed every Thursday and Friday at $9: 30$ a.m. and blood samples were taken every Wednesday at 8 : 45 a.m.

During test 2 (January 10-12, 1978), blood samples were taken every hour for 2 days. For a fechnical reason blood sampling was stopped on sheep $C$ during the second day, and only the results of the first complete day are given.

Test 3 was limited to a 24-hr period (March 16-17, 1978) and hourly food intake was also measured. Ketone bodies and glucose were assayed during tests 2 and 3 ; FFA analyses and determination of plasma lipid distributions were only carried out during test 2 . The other experimental procedures were the same as for test 1.

\section{Analysis.}

Acetoacetate and $\beta$-hydroxybutyrate assays were realized adapting the method of Curtius and Roth (1974), which is based on the reversible transformation of acetoacetate into $\beta$-hydroxybutyrate in the presence of $\beta$-hydroxybutyrate dehydrogenase, $\mathrm{NAD}^{+}$or NADH. The reaction was measured with a spectrophotometer on a $340 \mathrm{~nm}$ wavelength and the results were expressed in $\mathrm{mg} / \mathrm{l}$ of total blood.

We used the GOD-Perid test (Boehringer-Mannheim) for glucose assay. The reaction, catalyzed by glucose oxydase and peroxydase, liberates oxygen which reacts with the chromogen and forms a colored complex measured with a photometer at $436 \mathrm{~nm}$ wavelength. The results were expressed in $\mathrm{mg} / 100 \mathrm{l}$ of total blood.

The lipids were analysed after deproteinization of the plasma and extraction with an ethanol-ether mixture. The different classes of lipids were separated by thin layer chromatography on a silicagel $\mathrm{H} 60$ plate in the presence of petroleum benzine-acetone and then hexane. After development with Rhodamine 6G, the thin layer was measured by fluorescence-quenching densitometry. The FFA's scraped from the plate were esterified by benzine-methanol sulfuric acid and separated by gas chromatography on a 5 p. 100 EGSS-X column (gas chrom 80-100 mesh). Quantification of the total FFA was obtained with an internal standard method (hepta-decanoic acid, Christophe and Matthijs, 1966). The results were expressed in $\mathrm{mg} / 100 \mathrm{ml}$ of plasma. The food composition was ascertained by the usual methods : oven dessication for the dry matter content, muffle furnace incineration for the ash content, Kjeldahl's method for the nitrogen content and Weende's method for the crude fiber content. The protein content of the diet was defined as being the nitrogen content multiplied by 6.25 . 


\section{Results.}

Test 1. - The evolution of blood ketone body content is shown in figure 1. The mean values (means of hourly values for $48 \mathrm{hrs}$ ) of acetoacetate are 2.30 and $5.45 \mathrm{mg} / \mathrm{l}$ for sheep $A$ (overfed) and $B$ (underfed), respectively; those of $\beta$-hydroxybutyrate are 31.57 and $39.08 \mathrm{mg} / \mathrm{l}$, respectively. The blood ketone body concentration of sheep $B$ strongly increased at $11: 45$ a.m. and especially at $12: 45$ p.m., that is 1 to $2 \mathrm{hrs}$ after feeding. This high rate remained unchanged throughout the day and then gradually fell at night. In sheep A, blood ketone body levels rose slightly after feeding, but the daily evolution was not so clear as for sheep $B$.

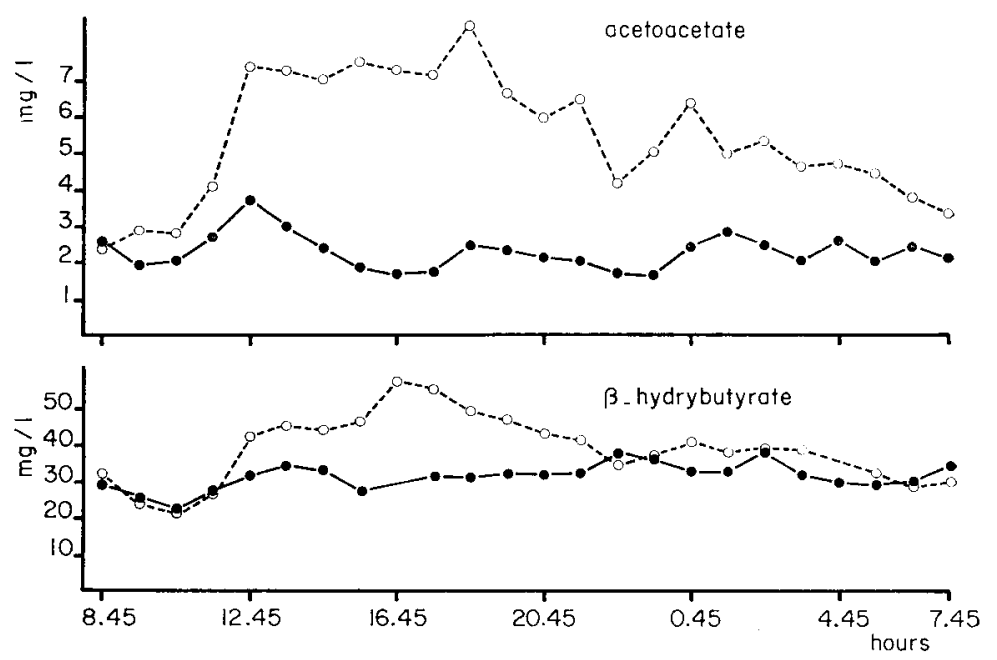

FIG. 1. - Daily changes in blood acetoacetate and $\beta$-hydroxybutyrate $(\mathrm{mg} / \mathrm{l})$ of sheep A (overfed, and $B$ (underfed, o-- -o) during fest 1 (each point represents the mean value of the 2 days).

The hourly evolution of total plasma FFA is represented in figure 2 . The average concentration (means of hourly values for $48 \mathrm{hrs}$ ) is $4.17 \mathrm{mg} / 100 \mathrm{ml}$ for sheep $A$ (overfed) and $1.85 \mathrm{mg} / 100 \mathrm{ml}$ for sheep $B$ (underfed). This FFA rate decreased at the end of the morning after feeding, but its evolution was not clear. Later, the rate remained stable in sheep B, whereas disorderly fluctuations appeared in sheep A.

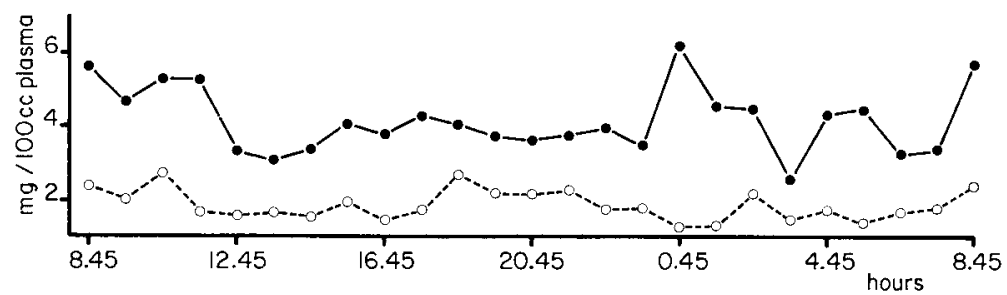

FIG. 2. - Daily changes in plasma free fatty acid content $(\mathrm{mg} / 100 \mathrm{ml}$ ) of sheep A (overfed, $\bullet-)$ ) and $B$ (underfed, $\circ---\circ$ ) during test 1 (each point represents the mean value of 2 days days). 
The mean values (means of hourly values for $48 \mathrm{hrs}$ ) for the different FFA's in p. 100 of total FFA are given in table 2. The hourly fluctuations of the principal FFA's showed no clear daily evolution.

TABLE 2

Means of hourly values (in p. 100 of total FFA)

\begin{tabular}{lccccccccc}
\hline & C14.0 & C 16.0 & C16.1 & C18.0 & C18.1 & C 18.2 & C18.3 & $C 20.4$ \\
\hline Sheep A & 1.8 & 25.3 & 0.6 & 39.3 & 31.5 & 0.3 & 0.3 & 0.0 \\
Sheep B & 4.5 & 38.5 & 0.8 & 24.6 & 23.2 & 5.5 & 5.5 & 0.0 \\
\hline
\end{tabular}

Test 2. - The evolution of the live weight $(\mathrm{kg})$ and the food intake ( $\mathrm{g}$ dry matter/ day $/ \mathrm{kg} \mathrm{W0.75}$ ) of sheep $C$ (overfed) and $D$ (control), during the experiment preceding the second test, are represented in figure 3 . The live weight shown in this figure is the mean value of 2 weighings per week; the food intake is the mean amount of the 7 daily values for one week.
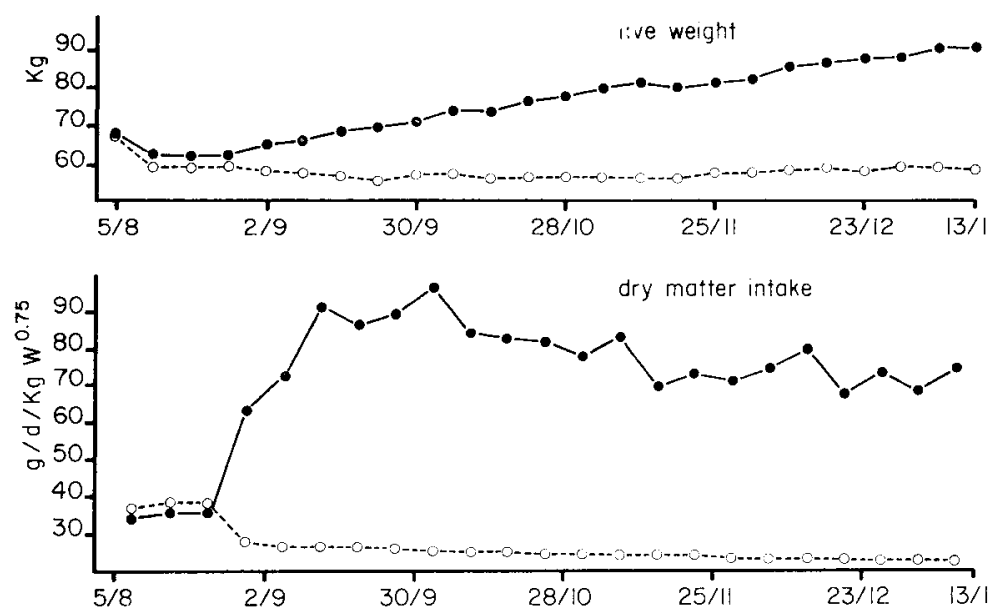

FIG. 3. - Evolution of live weight $(\mathrm{kg})$ and dry matter intake $\left(\mathrm{g} / \mathrm{d} / \mathrm{kg} \mathrm{W} \mathrm{W}^{0.75}\right)$, in sheep $C$ (overfed, $\left.\bullet-\bullet\right)$ and $D$ (check, o-- - o) before test 2. (Each point represents the means of two weekly weighings for live weight, and the means of seven daily measurements of intake).

The evolution of the ketone bodies is shown in figure 4 . The average concentrations of acetoacetate are 2.67 and $1.27 \mathrm{mg} / \mathrm{l}$ for sheep $C$ and $D$, respectively; those of $\beta$-hydroxybutyrate are 38.28 and 17.44, respectively. Both graphs show an increase after feeding, but the evolution is not as clear as in the first test, especially for sheep $D$.

The results of glucose concentration are also found in figure 4. The average values are $51.0 \mathrm{mg} / 100 \mathrm{ml}$ in sheep $C$ (overfed) and 41.4 in sheep $D$ (control). An 
increase of glycemia occurred at 2 : 45 p.m. ; another could apparently be observed at the beginning of the night, but it decreased as the night progressed.

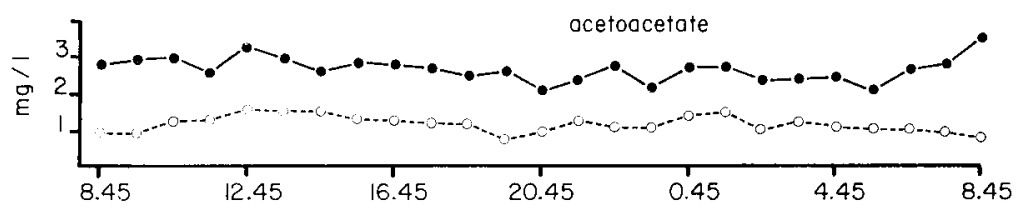

3. hydroxybutyrote
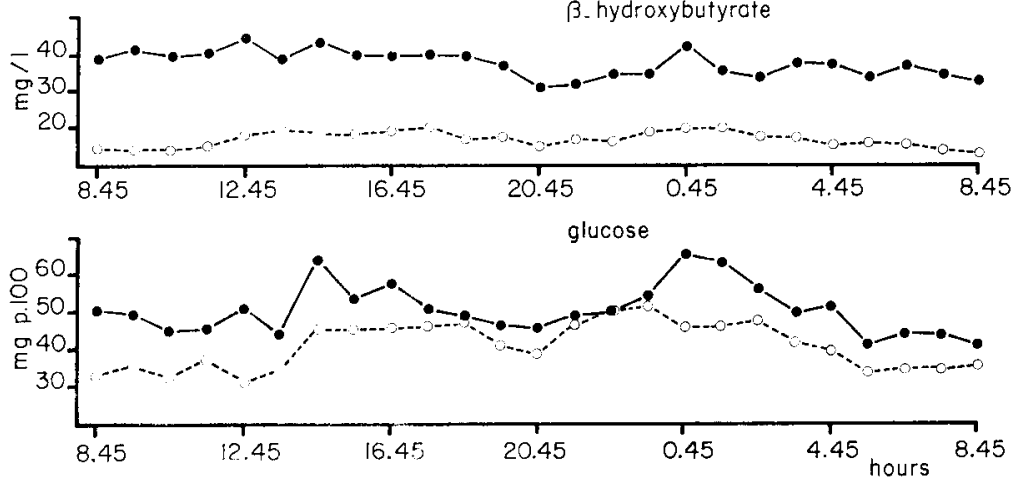

FIG. 4. - Daily changes in blood kefone bodies $(\mathrm{mg} / \mathrm{l})$ and glucose $(\mathrm{mg} / 100 \mathrm{ml}$ ) of sheep C (overfed, $-\bullet)$ and $D$ (check, o- - -0 ) during test 2 (for sheep $D$, each point represents the mean value of the 2 days)

The hourly evolution of total plasma FFA is represented in figure 5 . The mean values are $6.71 \mathrm{mg} / 100 \mathrm{ml}$ in sheep $C$ and $4.98 \mathrm{mg} / 100 \mathrm{ml}$ in sheep $D$. Disorderly fluctuations appeared in both sheep so that the influence of feeding could not be positively established. The distribution of FFA's is given in table 3 . The results of the hourly fluctuations of the major fatty acids indicated no clear evolution during the day.

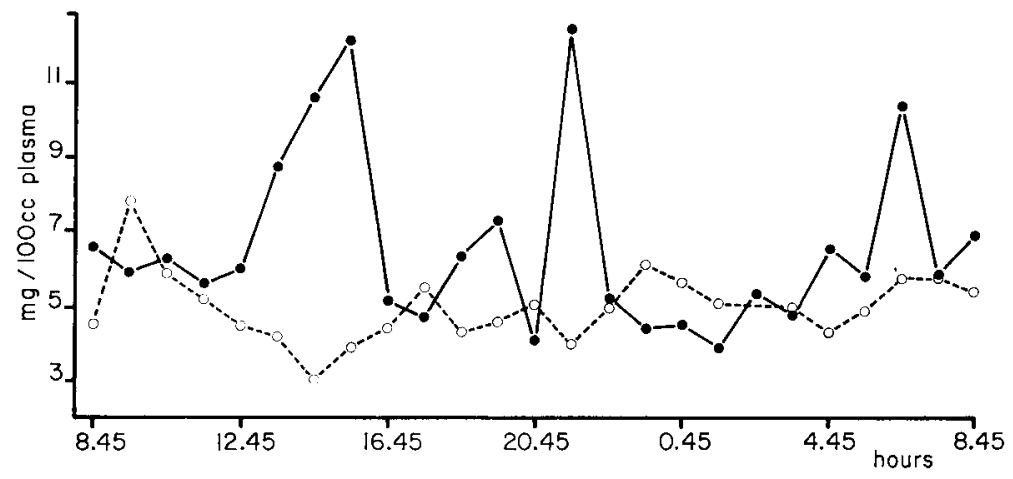

FIG. 5. - Daily changes in plasma free fatfy acid content $(\mathrm{mg} / 100 \mathrm{ml}$ ) of sheep C (overfed, - and $D$ (underfed, $0---0$ ) during test 2 (for sheep $D$, each point represents the mean value of the 2 days). 
TABLE 3

Means of hourly values (in p. 100 of total FFA)

\begin{tabular}{lccccccccc}
\hline & C14.0 & C16.0 & C 16.1 & C 18.0 & C18.1 & C 18.2 & C18.3 & C 20.4 \\
\hline Sheep C & 3.2 & 34.7 & 4.3 & 24.6 & 27.7 & 5.3 & 0.1 & 0.3 \\
Sheep D & 2.7 & 32.8 & 4.5 & 28.8 & 26.9 & 3.7 & 0.6 & 0.0 \\
\hline
\end{tabular}

TABLE 4

Mean value of plasma lipids (in p. 100 of total plasma lipids)

\begin{tabular}{|c|c|c|}
\hline & Sheep C & Sheep D \\
\hline 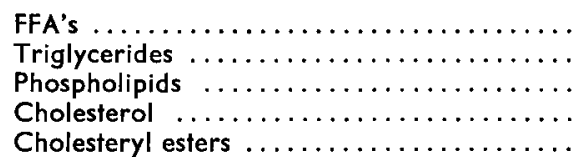 & $\begin{array}{l}19.7 \\
15.1 \\
26.6 \\
20.1 \\
18.5\end{array}$ & $\begin{array}{l}21.7 \\
11.9 \\
26.9 \\
17.4 \\
22.2\end{array}$ \\
\hline
\end{tabular}
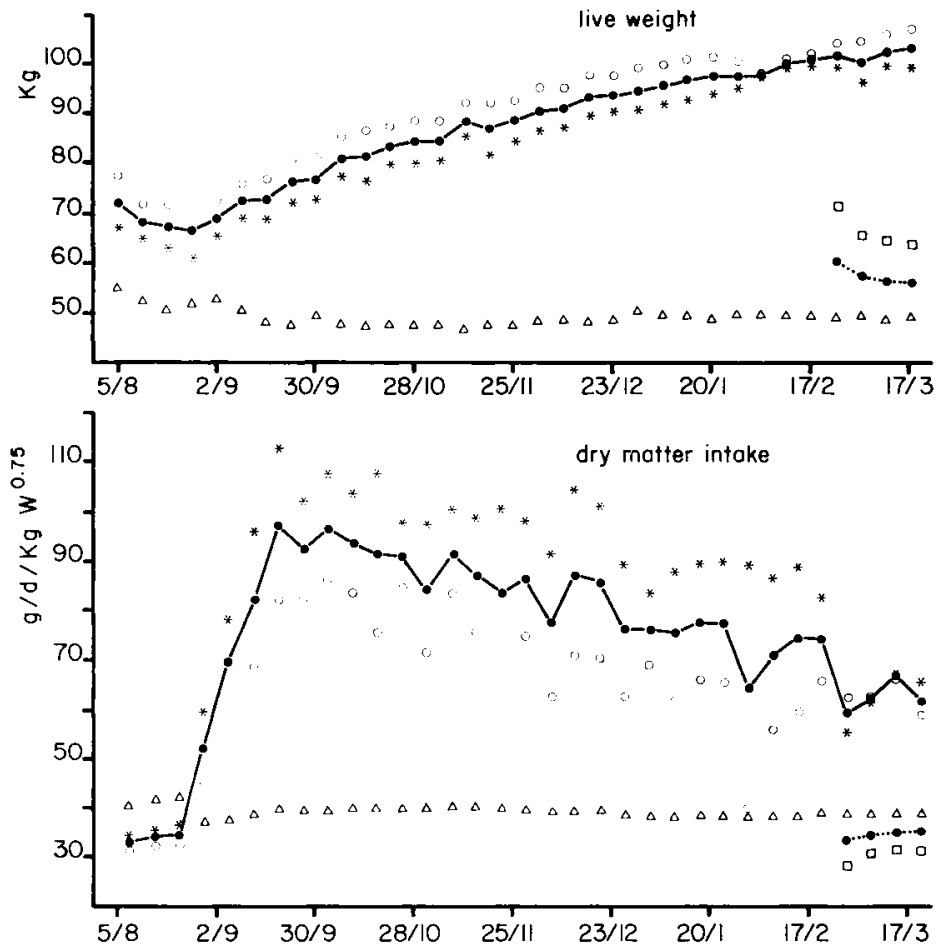

FIG. 6. - Evolution of live weight $(\mathrm{kg})$ and dry matter intake $\left(\mathrm{g} / \mathrm{d} / \mathrm{kgW} \mathrm{W}^{0.75}\right)$ in overfed $(*$ sheep $\mathrm{E}$, o sheep $\mathrm{F}, \bullet-$ means) and control ( $\triangle$ sheep G, a sheep $\mathrm{H}, \bullet---$ means) sheep before test 3 (each point represents the means of two weekly weighings for live weight, and the means of seven daily measurements of intake). 
The mean values of plasma lipids are given in table 4. The evolution of the percentage of different lipids with regard to total lipids during the day showed no evident evolution; the phospholipids might decrease during the day and increase during the night.

Test 3. - The live weight and voluntary food intake of the 4 sheep during the period preceding test 3 are represented in figure 6 . The graphs present exactly the same profiles as those of test 2 .

The results on ketone bodies are found in figures 7 and 8 . The mean values for aceloacetate are $2.56 \mathrm{mg} / \mathrm{l}$ (overfed sheep E), 2.46 (overfed sheep F), 1.98 (control
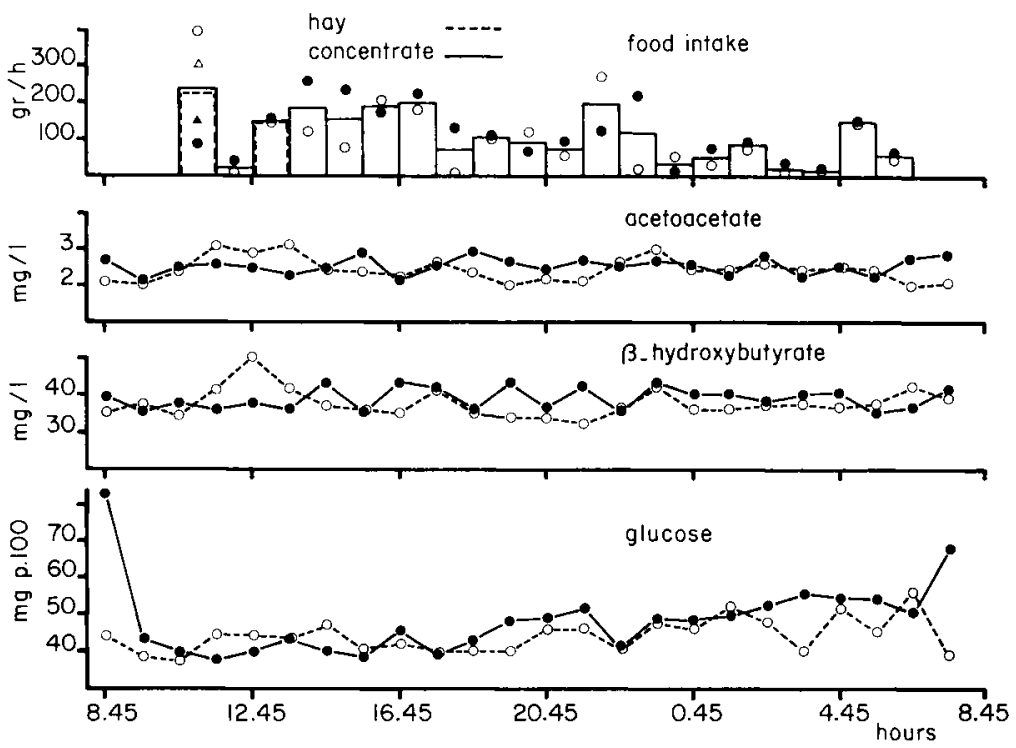

FIG. 7. - Daily changes in the blood ketone bodies $(\mathrm{mg} / \mathrm{l})$ and glucose $(\mathrm{mg} / 100 \mathrm{ml})$ of overfed sheep (๑- sheep E, O-- - 0 sheep F) compared with food intake $(\mathrm{g} / \mathrm{hr})$ during test 3 .

Food intake : - concentrate sheep E, $\Delta$ hay sheep $E$, o concentrate sheep $F, \Delta$ hay sheep $F$. In the third column values are very similar and concentrate intake are only mentioned.

TABLE 5

Statistical significance

\begin{tabular}{|c|c|c|c|c|}
\hline $\begin{array}{c}\text { Acetoacetate } \\
\text { Source of variation }\end{array}$ & Sum of squares & dl & Mean squares & F value \\
\hline 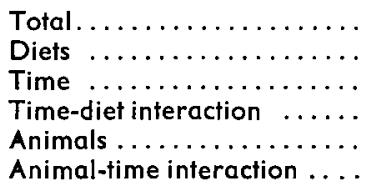 & $\begin{array}{r}25.4974 \\
2.1241 \\
8.6923 \\
4.2502 \\
2.6372 \\
7.7936\end{array}$ & $\begin{array}{r}95 \\
1 \\
23 \\
23 \\
2 \\
46\end{array}$ & $\begin{array}{l}2.1241 \\
0.3779 \\
0.1848 \\
1.3186 \\
0.1694\end{array}$ & $\begin{array}{l}1.6109 \mathrm{NS} \\
2.2308 \mathrm{~S} \\
1.0909 \mathrm{NS}\end{array}$ \\
\hline
\end{tabular}


sheep G) and 2.44 (control sheep $H$ ) ; the mean values for $\beta$-hydroxybutyrate are $39.16 \mathrm{mg} / \mathrm{l}$ (sheep E), 37.35 (sheep F), 33.21 (sheep G) and 36.30 (sheep H).
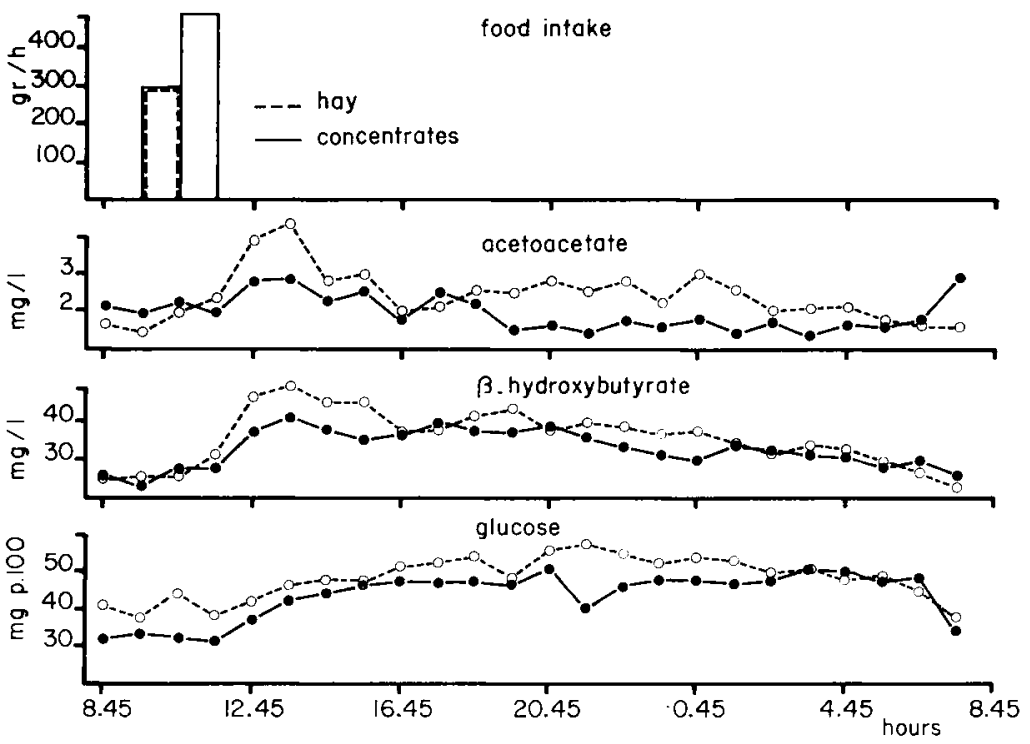

FIG. 8. - Daily changes in the blood ketone bodies $(\mathrm{mg} / \mathrm{l})$ and glucose $(\mathrm{mg} / 100 \mathrm{ml})$ of check sheep $(\bullet-G, 0---\circ$ sheep $H)$ compared with food infake $(\mathrm{g} / \mathrm{h})$ during test 3 .

Blood ketone body levels of the sheep on the maintenance diet (sheep $G$ and $\mathrm{H}$ ) strongly increased $2 \mathrm{hrs}$ after feeding. A limited increment of ketone bodies was also noticed at that moment in animals fed ad libitum. Moreover, we observed that every food intake was followed by an increase of ketone bodies in sheep $F$, which did not have as homogeneous a daily intake as sheep $E$.

The values obtained for ketone bodies were examined using analysis of variance with three factors : diets (fixed, crossed), time (fixed, crossed), animals (aleatory, nested to the diets). The $F$ values for the diets is the rate of variance between diets and between animals. The $F$ value, calculated for time and diet-time interaction, is the rate between factorial variance and variance of animal-time interaction (tables 5 and 6).

\section{TABLE 6}

Statistical significance

\begin{tabular}{|c|c|c|c|c|}
\hline $\begin{array}{l}\beta \text {-Hydroxybutyrate } \\
\text { Source of variation }\end{array}$ & Sum of squares & dl & Mean squares & Fvalue \\
\hline 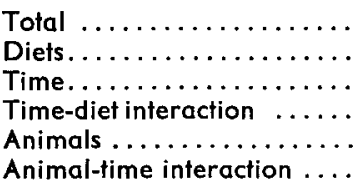 & $\begin{array}{r}13649.3859 \\
293.1956 \\
1881.8635 \\
1137.1133 \\
174.8576 \\
10162.3509\end{array}$ & $\begin{array}{r}95 \\
1 \\
23 \\
23 \\
2 \\
46\end{array}$ & $\begin{array}{r}293.1956 \\
81.8204 \\
49.4397 \\
87.4288 \\
220.9207\end{array}$ & $\begin{array}{l}1.3272 \mathrm{NS} \\
0.3704 \mathrm{NS} \\
0.2238 \mathrm{NS}\end{array}$ \\
\hline
\end{tabular}


The results show that the time of day has a significant effect on blood aceloacetate concentration, whereas dietary conditions are not significant.

No F's reach a significant level for $\beta$-hydroxybutyrate.

The results of glucose concentration are also shown in figures 7 and 8 . The mean values are $49.0 \mathrm{mg} / 100 \mathrm{ml}$ (sheep E), 44.7 (sheep F), 44.0 (sheep G), 48.6 (sheep H). For sheep $G$ and $H$ on the maintenance diet, there was a gradual increase during the day starting at $12: 45$ or $1: 45$ p.m., and a decrease at the end of the night. For sheep $E$ and $F$ fed ad libitum, the hourly results were sometimes widely different, but there also seemed to be an increase during the day and a sudden decrease during the night. The results obtained for glucose were also examined using analysis of variance (table 7).

The same conclusions may be drawn as for acetoacetate.

TABLE 7

Statistical significance

\begin{tabular}{|c|c|c|c|c|}
\hline $\begin{array}{c}\text { Glucose } \\
\text { Source of variation }\end{array}$ & Sum of squares & $\mathrm{dl}$ & Mean squares & F value \\
\hline $\begin{array}{l}\text { Total } \ldots \ldots \ldots \ldots \ldots \ldots \ldots \ldots \\
\text { Diet } \ldots \ldots \ldots \ldots \ldots \ldots \ldots \\
\text { Time } \ldots \ldots \ldots \ldots \ldots \ldots \\
\text { Time-treatment interaction } \ldots \\
\text { Animal } \ldots \ldots \ldots \ldots \ldots \ldots \\
\text { Time-animal interaction } \ldots \ldots \ldots\end{array}$ & $\begin{array}{r}5164.2609 \\
7.0959 \\
1577.3257 \\
1601.2585 \\
475.6867 \\
1502.8941\end{array}$ & $\begin{array}{r}95 \\
1 \\
23 \\
23 \\
2 \\
46\end{array}$ & $\begin{array}{r}7.0959 \\
68.5794 \\
69.6199 \\
237.8434 \\
32.6716\end{array}$ & $\begin{array}{l}<1 \mathrm{NS} \\
2.099 \mathrm{~S} \\
2.131 \mathrm{~S}\end{array}$ \\
\hline
\end{tabular}

\section{Discussion.}

Food ingestion induces various modifications in the blood composition of all animals. In sheep (Thye, Warner and Miller, 1970) and in cattle (Coggins and Field, 1976), the blood ketone body level increases after feeding. We also observed this in our tests. The values given for glycemia are contradictory. Our results fit with those of Günzel and Giesecke (1974) on sheep and of Blom, Halse and Hove (1976) on bulls ; these authors found an increase of glycemia after feeding. In contrast, Coggins and Field (1976) and Hart ef al. (1975) observed a decrease after feeding in cattle, and Thye, Warner and Miller (1970) described an increment after an initial fall. Some authors (Coggins and Field, 1976 ; Günzel and Giesecke, 1974 ; Hart ef al., 1975 ; Thye, Warner and Miller, 1970) observed a reduction of the FFA's after feeding, followed by a progressive rise. Rindsig and Schultz (1974) could not establish such a clear evolution, and neither could we from our results.

It becomes evident for this bibliographical review that the large increase of blood ketone bodies in ruminants after feeding does not originate from an increased concentration of blood FFA's. Neither does it arise from an excess of glucose since our findings show that the increase of blood ketone bodies 1 to 2 hrs after feeding precedes that of glycemia by 1 to $3 \mathrm{hrs}$. The transformation of volatile substances, and more 
particularly butyric acid, into $\beta$-hydroxybutyrate in the rumen wall is evidently the reason for the high increase of ketone bodies. The consequence for ruminants is a high $\beta$-hydroxybutyrate/acetoacetate ratio ( 7.2 to 16.8 in our assays), while this ratio is about 1 in rats (de Gasquet ef al., 1977).

Our results also suggest an increase of glycemia at the beginning of the night, sometimes followed by a sudden decrease. The same evolution was observed by Blom, Halse and Hove (1976) and Hart ef al. (1975) for cattle, while Siers and Trenkle (1973) noted a reduction of glycemia during the day for pigs fed ad libitum. On the contrary, the glycemia of rats, which are nocturnal animals, shows a reduction during the night (de Gasquet ef al., 1977).

The effects of food intake level on mean daily blood composition vary according to the blood substance. Coggins and Field (1976) noted no effect of the level of food intake on the ketone body concentration. In the present study, the mean daily values observed in underfed or control animals are superior to (test 1), lower than (test 2) or equal to (test 3 ) those observed in overfed animals. This is due to individual variations since the analysis of variance carried out on test 3 results emphasizes that there is no significant difference between the dietary treatments as concerns acetoacetate.

McClure (1977) working on cattle, observed no effect of food level intake on glycemia. The results of the present study show a higher mean daily value of glycemia in overfed sheep than in control sheep during test 2 , but this is certainly due to individual differences since the variance analysis of test 3 does not show any significant differences between feeds.

Coggins and Field (1976) reported a decrease of blood FFA's with a rise of food intake in caftle. During our first two tests, we observed the opposite, but we were unable to conclude if this was due to food intake or to individual differences. The same holds true for the distribution of FFA's and of blood lipids.

The level of food intake has a variable effect on the daily evolution of the different blood components. Our results are consistent with those of de Gasquet ef al. (1977), who concluded that the amplitude of the daily ketone body graph depended on food conditions. This amplitude was higher in animals eating all their daily food in a few meals, while the fluctuations were small in animals fed ad libitum and distributing their food intake throughout the day. On the contrary, there was no significant effect of food intake level on blood glucose content or on the composition of blood lipids. In rat, de Gasquet ef al. (1977) observed divergent FFA evolutions during the day, according to the food eaten.

We have come to the conclusion that blood components are the least dependent on immediate food conditions in the morning before the first food intake, and, consequently, any variations in blood components related to body weight and composition would be perceived at that time.

Reçu en juin 1978.

Accepté en octobre 1978.

Acknowledgements. - This work was supported by the Institut pour l'Encouragement de la Recherche Scientifique dans l'Industrie ef l'Agriculture (IRSIA), rue de Crayer, B-1050 Brussels, Belgium. 
Résumé. Dans le but de rechercher l'évolution journalière de la concentration de diverses substances sanguines chez des moutons soumis à des niveaux d'ingestion très variables, des prises de sang ont été réalisées toutes les heures au cours de 3 périodes de 24 ou $48 \mathrm{~h}$. Les animaux étaient sous-alimentés, nourris de manière à couvrir approximativement les besoins d'entretien ou ad libitum.

Généralement, une augmentation des concentrations en acéto-acétate et en $\beta$-hydroxybutyrate se produit rapidement $(1$ à $2 h$ ) après les repas. Les fluctuations journalières sont beaucoup plus grandes chez les animaux nourris de façon limitée que chez ceux ayant continuellement accès à la nourriture. La concentration journalière moyenne du sang en corps cétoniques dépend certainement davantage de différences individuelles que du niveau d'ingestion.

Les ingestions d'aliments provoquent également une augmentation de la glycémie, mais elle est moins nette et plus tardive ( 3 à $4 \mathrm{~h}$ ) que celle des corps cétoniques. Une augmentation nocturne de la glycémie paraît en plus se produire. Le niveau d'ingestion des aliments n'a d'effet ni sur la glycémie moyenne journalière, ni sur l'évolution durant la journée.

Nos résultats ne nous permettent pas de conclure à une évolution ordonnée de la composition de la fraction lipidique du sang (répartition des lipides, concentration en AGL totaux, répartition des acides gras libres) au cours de la journée. II n'est pas non plus possible de conclure à un effet du niveau d'ingestion sur ces paramètres.

\section{References}

BLOM A. K., HALSE K., HOVE K., 1976. Growth hormone, insulin and sugar in the blood plasma of bulls. Interrelated diurnal variations. Acta endocr., 82, 758-766.

CHRISTOPHE A., MATTHIJS F., 1966. New method for the determination of the fatty acid pattern of serum lipid classes. Clin. chim. Acta, 16, 39-43.

COGGINS C. R. E., FIELD A. C., 1976. Diurnal variation in the chemical composition of plasma from lactating beef cows on three dietary energy intakes. J. agric. Sci., Camb., 86, 595-602.

CURTIUS D. E., ROTH M., 1974. Clinical biochemistry, Parey, Berlin, pp. 922.

DE GASQUET P., GRIGLIO S., PEQUIGNOT-PLANCHE E., MALEWIAK M. I., 1977. Diurnal changes in plasma and liver lipids and lipoproteins lipase activity in heart and adipose tissue in rats fed a high and low fat diet. J. Nutr., 107, 199-212.

GUNZEL R., GIESECKE D., 1974. The influence of feeding, fasting and phloridzin diabetes on the relationships between free fatty acids and glucose in the blood of sheep. Z Zl. Vet Med. A, 21, 279-284.

HART I. C., BINES J. A., BALCH C. C., COWIE A. T., 1975. Hormone and metabolite differences between lactating beef and dairy cattle. Life Sci., 16, 1285-1292.

MCCLURE T. J., 1977. Effects of food intake and composition on the concentration of glucose in the blood of lactating cattle. Austr. J. agric. Res., 28, 333-339.

RINDSIG R. B., SCHULTZ L. H., 1974. Effects of abomasal infusions of safflower oil or elaidic acid on blood lipids and milk fat in dairy cows. J. Dairy Sci., 57, 1459-1466.

SIERS D. G., TRENKLE A. H., 1973. Plasma levels of insulin, glucose, growth hormone, free fatty acids and amino acids in resting swine. J. ani. Sci., 37, 1180-1185.

THYE F. W., WARNER R. C., MILLER P. D., 1970. Relationship of various blood metabolites to voluntary feed intake in lactating ewes. J. Nutr., 100, 565-572. 